Studia nad Autorytaryzmem i Totalitaryzmem 42, nr 4

Wrocław 2020

https://doi.org/10.19195/2300-7249.42.4.19

MARTA BARANOWSKA

ORCID: 0000-0002-0365-1023

Uniwersytet Mikołaja Kopernika w Toruniu

mb1@law.umk.pl

\title{
Noam Chomsky o systemie władzy w Stanach Zjednoczonych, czyli amerykański sen o demokracji
}

\begin{abstract}
Abstrakt: Celem badawczym artykułu jest analiza poglądów Noama Chomsky'ego dotyczących ustroju Stanów Zjednoczonych, które zawarł w książce Requiem dla amerykańskiego snu. 10 zasad koncentracji bogactwa $i$ władzy. Pytania badawcze dotyczą roli prawa pozytywnego w relacjach władzy: czy wyznacza ono faktyczną strukturę władzy, czyli uprawnienia poszczególnych instytucji, czy też jest tylko formą kamuflującą rzeczywistość? Innymi słowy, czy system prawny, a przede wszystkim Konstytucja, jest filarem czy też fasadą struktur władzy? Metodami badawczymi są metoda analizy treści tekstu zawierającego poglądy polityczne dotyczące struktur władzy autorstwa Chomsky’ego oraz analiza systemowa (makrosystemowa).

Zdaniem Chomsky'ego mamy do czynienia z koncentracją bogactwa i władzy w rękach niewielkiej grupy najbogatszych. Jego poglądy wpisują się w nurt ideowy amerykańskiej Nowej Lewicy. Chomsky starał się opisać współczesny system władzy i negatywne konsekwencje tego stanu rzeczy. Jednocześnie podkreślał, że poprzednie pokolenia wywalczyły całkiem sporą sferę wolności dla społeczeństwa, dzięki czemu ma ono wyjątkową możliwość, by zmienić istniejący stan rzeczy. W celu dotarcia do jak największej liczby czytelników Chomsky swoje poglądy przedstawił prostym językiem i wypunktował faktyczne zasady funkcjonowania struktur władzy w Stanach Zjednoczonych. Pokazał, w jaki sposób przejmują oni efektywnie kontrolę nad społeczeństwem i politykami. Wnioski, jakie można wyprowadzić z jego rozważań, są takie, że w obecnym stanie rzeczy mamy do czynienia z hipokryzją systemu polegającą na dysonansie między zapisami Konstytucji i systemem prawa ustanawiającym system demokracji przedstawicielskiej a rzeczywistością polityczną. Chomsky podkreślał, że amerykański sen o demokracji się nie ziścił, bo większość społeczeństwa nie ma żadnego wpływu na faktyczne decyzje polityków. Oznacza to, że system władzy nie gwarantuje realizacji wprost zapisanych zasad prawa, ponieważ jego interpretacja i stosowanie są zależne od interesów podmiotów faktycznie dzierżących władzę, której źródłem jest wyłącznie bogactwo. Chomsky jest jednym z przedstawicieli Nowej Lewicy, według której istniejące struktury władzy należy określić mianem „państwa korporacyjnego”, a jego znamienną cechą jest
\end{abstract}


totalitaryzm, oparty nie na brutalnej przemocy, lecz na „represji psychicznej” godzącej w indywidualność ludzi. Celem Chomsky’ego jest demaskacja faktycznych struktur władzy, ponieważ uważał, że świadomi tych mechanizmów obywatele dzięki wolności zrzeszania się i wolności słowa są w stanie zmienić ten stan rzeczy.

Słowa kluczowe: Noam Chomsky, amerykański sen, demokracja, władza, Nowa Lewica.

\title{
NOAM CHOMSKY ON THE SYSTEM OF POLITICAL POWER IN THE UNITED STATES OF AMERICA, OR THE AMERICAN DREAM OF DEMOCRACY
}

\begin{abstract}
The aim of the article is to analyze Noam Chomsky's views on the system in the United States, which he included in his book Requiem for the American Dream: The 10 Principles of Concentration of Wealth \& Power. Research questions that are the subject of analysis are issues related to the role of positive law in power relations. Does it determine the actual structure of power, namely does it set the powers and limitations of individual institutions, or is it just an idea camouflaging reality? In other words, is the legal system and, above all, is the Constitution a pillar or a facade of power structures? The research was conducted using the method of analyzing the text's content including Chomsky's political views on power structures and system (macrosystem) analysis.

According to Chomsky, we are dealing with a concentration of wealth and power in the hands of a small group consisting of the richest. His views fit into the ideological current of the American New Left. Chomsky tries to describe the modern system of power and describes the negative consequences of this state of affairs. At the same time, he emphasizes that previous generations won quite a large range of freedom for society, thanks to which it had a unique opportunity to change this state of affairs. In order to reach as many readers as possible, Chomsky presents his views in plain language and points out the actual principles of the functioning of power structures in the United States. He shows how they effectively take control over society and politicians. The conclusions that can be drawn from his considerations are that in the current state of affairs we are dealing with hypocrisy of the system consisting in dissonance between the provisions of the Constitution and the legal system establishing the system of representative democracy, and the political reality. Chomsky emphasizes that the American dream of democracy has not come true, because the majority of society has no influence on the actual decisions made by politicians. This means that the power system does not guarantee the implementation of explicitly written principles of law because its interpretation and application depends on the interests of the entities actually wielding power, whose source is exclusively wealth. Chomsky is one of the representatives of the New Left, according to which the existing structures of power should be described as a "corporate state," and its characteristic feature is totalitarianism, based not on brutal violence, but on "psychological repression" against the individuality of people. Chomsky's goal is to unmask the actual structures of power because he believes that citizens aware of these mechanisms, thanks to the freedom of association and freedom of speech, are able to change this state of affairs.
\end{abstract}

Keywords: Noam Chomsky, American Dream, democracy, power, New Left. 


\section{Wstęp}

Krytyczna refleksja nad rzeczywistością społeczno-polityczną zawsze miała wielkie znaczenie, ale obecnie jest ona szczególnie istotna. Noam Chomsky zwrócił uwagę, że właśnie teraz jesteśmy w tym punkcie historii, w którym odpowiedź na pytanie „Co możemy zrobić?” brzmi:

Prawie wszystko, co postanowimy. Sprawa wygląda tak, że według standardów porównawczych żyjemy w całkiem wolnym społeczeństwie. Nie był to dar niebios. Swobody wywalczyliśmy w twardej, bolesnej, odważnej walce i teraz je mamy. Mamy tę spuściznę — spuściznę, którą zawdzięczamy walkom prowadzonym przez innych ${ }^{1}$.

Jednym z głosów w dyskusji o współczesnym ustroju i polityce Stanów Zjednoczonych jest właśnie ten autorstwa Noama Chomsky’ego (ur. 7.12.1928). Jest on emerytowanym profesorem lingwistyki na Massachusetts Institute of Technology (MIT), jednym z wybitniejszych naukowców, który wraz z Morrisem Hallem stworzył gramatykę transformacyjno-generatywną, oraz teoretykiem polityki i aktywistą. Uznawany jest za jednego z największych krytyków polityki zagranicznej Stanów Zjednoczonych, dążenia tego państwa do geopolitycznej hegemonii oraz neoliberalnego kapitalizmu i korporacyjnych mediów ${ }^{2}$.

Celem badawczym artykułu jest analiza poglądów Chomsky'ego dotyczących struktury władzy w Stanach Zjednoczonych, które zawarł w książce Requiem dla amerykańskiego snu. 10 zasad koncentracji bogactwa $i$ wtadzy, opartej na filmie Requiem for the American Dream ${ }^{3}$. Jego rozważania skłaniają również do refleksji nad fundamentalną kwestią, mianowicie rolą prawa. Czy wyznacza ono faktyczną strukturę władzy, czyli uprawnienia poszczególnych instytucji, czy też jest tylko formą kamuflującą rzeczywistość? Innymi słowy, czy system prawny, a przede wszystkim Konstytucja, jest filarem czy też fasadą struktur władzy?

\section{Idea amerykańskiego snu}

Punktem wyjścia rozważań Chomskiego jest idea amerykańskiego snu. Jest to jedno z bardziej znanych pojęć obecnych w świadomości Amerykanów. Jako pierwszy użył go James Truslow Adams w książce The Epic of America opublikowanej w $1931 \mathrm{roku}^{4}$. Jim Cullen podkreślał, że to nie pochodzenie, więzy

${ }^{1}$ N. Chomsky, Requiem dla amerykańskiego snu. 10 zasad koncentracji bogactwa $i$ władzy, przeł. S. Baranowski, Kraków 2018, s. 147-148.

2 Zob. C. Garland, Noam Chomsky, [hasło w:] The International Encyclopedia of Revolution and Protest: 1500 to the Present, red. I. Ness, Oxford-New York 2009, s. 738-739.

${ }^{3}$ Requiem for the American Dream, reż. P.D. Hutchison, K. Nyks, J.P. Scott, premiera: 18.04.2015.

${ }^{4}$ Zob. J.T. Adams, The Epic of America, Boston 1931, https://archive.org/stream/in.ernet.dli. 2015.262385/2015.262385.The-Epic_djvu.txt (dostęp: 12.01.2020). 
krwi, język czy kultura, lecz niejednoznaczna, niezwykle elastyczna i wciąż aktualna idea amerykańskiego snu kształtuje tożsamość Amerykanów ${ }^{5}$. W rzeczywistości koncepcja ta zawiera w sobie kilka „snów”, których rozumienie zmieniało się z czasem ${ }^{6}$. Adams, który opublikował swoją książkę w czasach wielkiego kryzysu, próbując zdiagnozować jego przyczyny, stwierdził, że Amerykanie popełnili błąd, koncentrując się zbytnio na dobrobycie materialnym i zapominając o wyższych marzeniach i aspiracjach, na których opierał się ich kraj. Amerykański sen wyrażał przecież ideały wyrażone w Deklaracji Niepodległości i ugruntowane w Konstytucji: prawo do życia, wolności, równości, dążenia do szczęścia oraz demokracji.

Cullen, analizując wybrane przez siebie koncepty amerykańskiego snu, takie jak dążenie do szczęśliwego życia, niezależności politycznej, równości praw, dobrobytu, jednocześnie zwrócił uwagę, że faktycznie rekonstruuje on różne znaczenia wolności obecne w kulturze i polityce amerykańskiej od jej zarania. Wprawdzie często są one sprzeczne (na przykład wolność do uczestnictwa i zobowiązań politycznych oraz wolność od uczestnictwa i zobowiązań politycznych), to wszystkie sprowadzają się do poczucia sprawczości, czyli możliwości realizowania własnych marzeń ${ }^{7}$. Istotnym elementem jest również etos ciężkiej pracy, dzięki której wszystko w Ameryce staje się możliwe. Cullen zwrócił uwagę, że współcześnie istnieje, a może nawet dominuje, forma amerykańskiego snu, którą określił mianem Dream of the Coast. Jest to marzenie o sławie i fortunie, która zostanie osiągnięta bez oczywistego wysiłku, czego egzemplifikacją są Hollywood i celebryci ${ }^{8}$.

5 „The omnipresence of »the American Dream« stems from a widespread though not universal belief that the concept describes something very contemporary. At the same time, however, much of its vitality rests on a premise, which I share, that it is part of a long tradition"; J. Cullen, The American Dream: A Short History of an Idea That Shaped a Nation, Oxford 2003, s. 5.

6 „There are many American Dreams, their appeal simultaneously resting on their variety and their specificity. What James Truslow Adams called in the epilogue of The Epic of America »that dream of a land in which life should be better and richer and fuller for every man « may be fine as far as it goes, but the devil is in the details: just what does »better and richer and fuller « mean? The answers vary. Sometimes »better and richer and fuller « is defined in terms of money — in the contemporary United States, one could almost believe this is the only definition — but there are others. Religious transformation, political reform, educational attainment, sexual expression: the list is endless. These answers have not only been available at any given time; they have also changed over time and competed for the status of common sense"; ibidem, s. 7.

7 „One of the greatest ironies - perhaps the greatest - of the American Dream is that its foundations were laid by people who specifically rejected a belief that they did have control over their destinies. In its broadest sense, you might say that the narrative arc of this book begins with people who denied their efforts could affect their fates, moves through successors who later declared independence to get that chance, to heirs who elaborated a gospel of self-help promising they could shape their fates with effort, and ends with people who long to achieve dreams without having to make any effort at all"; ibidem, s. 10.

8 Ibidem, s. 199-200. 
Noam Chomsky rozpoczął swoją książkę wspomnieniem, że jeszcze w czasach wielkiego kryzysu amerykański sen był częścią świadomości społecznej. Ludzie wierzyli, że ciężką pracą poprawią swój los (idea self-made man). Ten mit utrzymywały między innymi krótkie powieści dziewiętnastowiecznego pisarza Horatia Algera, które ilustrowały drogę bohaterów „od pucybuta do milionera"9. Ciężką pracą realizowali oni amerykański sen, zdobywając szacunek oraz pozycję wśród — przynajmniej — klasy średniej. Chomsky przyznaje, że po części ten mit był wówczas prawdą, bo chociażby jego rodzinie, która przybyła do Ameryki w 1913 roku, udało się stać klasą średnią, a on sam miał możliwość ukończyć college i zająć się pracą naukową. W XXI wieku natomiast, choć sytuacja ekonomiczna większości rodzin jest lepsza niż w czasach wielkiego kryzysu, a mit amerykańskiego snu nadal jest podtrzymywany przez polityków, to swoją książkę Chomsky zatytułował Requiem dla amerykańskiego snu. Jego zdaniem w obecnej sytuacji amerykański sen o demokracji, wolności, równości i karierze „od pucybuta do milionera" nie jest realizowany. Demokracja, która polega na współuczestnictwu większości w podejmowaniu decyzji za pośrednictwem wybieralnych przez nich polityków, którzy słuchają opinii publicznej, faktycznie nie istnieje. Koncentracja bogactw prowadzi do koncentracji władzy, o czym już w 1776 roku pisał Adam Smith.

Czytamy słynne Bogactwo Narodów, gdzie napisano, że w Anglii „głównymi architektami polityki” są ludzie, którzy posiadają społeczeństwo — w tamtych czasach byli to „kupcy i wytwórcy". [...] Teraz nie są to już kupcy i wytwórcy, są to instytucje finansowe i wielonarodowe korporacje. Ludzie, których Adam Smith nazwał „władcami ludzkości” [...] prowadzą politykę, która przynosi im korzyści i szkodzi wszystkim innym ${ }^{10}$.

Najbogatsi kontrolują politykę, to oni sponsorują coraz droższe kampanie wyborcze, dzięki czemu mają bezpośredni wpływ na polityków, którzy tworzą ustawy stwarzające warunki koncentrowania bogactw przez swoich sponsorów, kosztem większości społeczeństwa. Chomsky uważa, że w ten sposób skonstruowana władza przez ostatnie 30 lat ugruntowała nierówności w niespotykanej do tej pory skali. Klasa średnia coraz bardziej się kurczy, a rozwiązania społeczno-ekonomiczne czynią niemożliwym realizację amerykańskiego snu, zgodnie z którym ciężką pracą jest się w stanie wydostać się z biedy. O marzeniu o demokracji, wolności, równości i dobrobycie Chomsky pisze bardzo dobitnie: „Wszystko to runęło" 11 .

Często opowieści zaczynają się od czegoś złego: „Źle się dzieje w państwie duńskim" ${ }^{2}$. Poczucie beznadziei, otarcie się o dno, motywuje, by wymyślić sposób

9 Na temat Horatia Algera zob. https://www.horatioalgersociety.net/100_biography.html (dostęp: 12.01.2020).

${ }^{10}$ N. Chomsky, Requiem..., s. 10.

11 Ibidem, s. 7.

12 W. Shakespeare, Tragiczna historia Hamleta, księcia Danii, przeł. M. Słomczyński, Kraków 2004, s. 35 . 
wydostania się z otchłani. Chomsky stara się opisać współczesny system władzy, by pokazać, że ,źle się dzieje”, ale czyni to, bo wierzy, że mamy wyjątkową możliwość, by ten stan rzeczy zmienić. Jak pisał, poprzednie pokolenia wywalczyły dla nas całkiem sporą sferę wolności. W celu dotarcia do jak największej liczby czytelników Chomsky swoje poglądy przedstawia prostym językiem i wypunktowuje faktyczne zasady funkcjonowania struktur władzy w Stanach Zjednoczonych.

\section{Dziesięć podstawowych zasad funkcjonowania struktur władzy według Chomsky’ego}

1. Uszczuplić demokrację. Chomsky zwraca uwagę, że od początku historii Stanów Zjednoczonych istniało napięcie między społeczeństwem, które pragnęło wolności i demokracji, oraz elitami dążącymi do utrzymania władzy i dominacji. James Madison, główny twórca Konstytucji, uważał, że władzę powinni sprawować bogaci, bo to im leży na sercu dobro publiczne i są oni o wiele bardziej odpowiedzialni. Przyczynił się on do tego, że większą część władzy usytuowano w Senacie, który na początku nie był wybieralny. Jego zdaniem system konstytucyjny powinien chronić bogatą mniejszość przed bogatą większością, ta bowiem, gdyby tylko miała taką możliwość, niechybnie przejęłaby majątki właścicieli ziemskich. Madison jednocześnie popierał demokratów, a nie arystokratów, co jawi się jako niespójność ${ }^{13}$. Chomsky zwrócił uwagę, że już Arystoteles dostrzegał to, czego obawiał się Madison: konsekwencją demokracji może być zebranie się większości biednych, by odebrać własność garstce bogatych. Zaproponowali oni jednak inne rozwiązania tej sytuacji: Madison wprowadził „uszczuplenie demokracji”, czyli większość władzy oddał w ręce bogatych, by nie byli zagrożeni przez biednych, Arystoteles zaś uważał, że rozwiązaniem byłoby zmniejszenie nierówności poprzez działania, które używając współczesnej terminologii, określilibyśmy mianem państwa opiekuńczego ${ }^{14}$. Chomsky oczywiście uważa, że droga Arystotelesa jest tą właściwą: mniej nierówności i więcej demokracji.

13 Także Alexander Hamilton uważał, że władza powinna być w rękach najlepszych (men of best quality), a nie narodu, który opisywał on jako zdeprawowaną i zepsutą ,wielką bestię”. Za czasów prezydentury Woodrowa Wilsona zaczęło znów dominować przekonanie, że „w kraju należy bronić systemu, w którym elity podejmują decyzje, a społeczeństwo je zatwierdza — »poliarchii« w języku politologii - a nie demokracji”; N. Chomsky, Hegemonia albo przetrwanie. Amerykańskie dążenie do globalnej dominacji, przeł. W. Turopolski, Warszawa 2005, s. 11-12.

14 „Gdzie zaś są dochody, nie należy tak postępować, jak to obecnie czynią demagogowie, którzy rozdzielają nadwyżki skarbowe. Bo lud bierze, ale zaraz potem znów znajduje się w takiej samej potrzebie, gdyż taka pomoc biednym jest jak ta dziurawa beczka. Przeciwnie, prawdziwy przyjaciel ludu musi baczyć na to, aby masy nie były zbyt biedne, ponieważ to bywa przyczyną rozkładu demokracji. Trzeba więc wynaleźć środki, aby zapewnić trwały dobrobyt ludności, gdyż jest to korzystne i dla zamożnych. Należy zatem nadwyżki dochodów gromadzić i następnie wszystko naraz rozdzielić między ubogich, najlepiej zaś jest, jeśli się zdoła tyle zebrać, by każdy mógł sobie kupić małą posiadłość, albo przynajmniej, żeby to starczyło na podjęcie jakiegoś handlu czy gospo- 
W przypadku Stanów Zjednoczonych należy też pamiętać, że wolność i bogactwo dla elity powstawało w wyniku ludobójstwa rdzennych mieszkańców oraz niewolnictwa. Podobnie jak na całym świecie również tu kobiety, czyli połowa ludności, nie miały prawie żadnych praw. Sytuacja różnych wykluczonych grup zmieniała się stopniowo, a duże znaczenie miały ruchy Nowej Lewicy lat sześćdziesiątych. Chomsky przytoczył słowa Malcolma X, który mówił wprost, że twierdzenia o demokracji w Ameryce są czystą hipokryzją. Ustrój demokratyczny gwarantuje wolność, równość, sprawiedliwość, a tych gwarancji nie doświadczały miliony dyskryminowanych czarnoskórych obywateli ${ }^{15}$. Ruchy lat sześćdziesiątych przyniosły zmiany, ale do dziś istnieją pozostałości tych form dyskryminacji.

2. Kształtować ideologię. Ruchy egalitarystyczne lat sześćdziesiątych wywołały silną reakcję uprzywilejowanych sił ekonomicznych w latach siedemdziesiątych. Aktywna stała się zarówno prawa strona sceny politycznej, jak i skrajni liberałowie. Chomsky wskazał na słynne Memorandum Powella z 1971 roku, w którym późniejszy sędzia Sądu Najwyższego, Lewis F. Powell Jr., stwierdził, że biznes traci kontrolę nad społeczeństwem zwracającym się w kierunku lewicy ${ }^{16}$. Nawoływał on biznes, żeby wykorzystał swoje „talenty”, by uratować swoją władzę. Ze strony skrajnych liberałów pojawił się w 1975 roku raport Komisji Trójstronnej The Crisis of Democracy, w którym znajduje się sformułowanie o „nadmiarze demokracji”, która ma według nich zgubny wpływ na funkcjonowanie państwa oraz biznesu. „Ludzie nie czuli już dawnego przymusu posłuszeństwa wobec tych, których poprzednio uważali za starszych, wyższych rangą, mających wyższy status" ${ }^{17}$. Komisja Trójstronna jednocześnie proponowała środki zaradcze, by utrzymać „większy umiar w demokracji”. Chomsky zwrócił uwagę, że od początku lat siedemdziesiątych politycy również zaczęli wprowadzać pewne działania, które miały zapobiec radykalizacji młodzieży. Przykładowo czesne w college'ach zaczęło szybko rosnąć, co spowodowało, że wykształcenie stało się w mniejszym stopniu dostępne, natomiast ci, którzy decydowali się na pożyczki, kończyli z długiem, który zniechęcał do jakichkolwiek radykalnych wystąpień przeciwko władzy politycznej i ekonomicznej.

darstwa wiejskiego. [...] Ze strony ludzi zamożnych jest to jest to zarówno szlachetnie, jak i rozumnie, jeśli dostarczają, każdej pewnej grupie ubogich, odpowiednich środków umożliwiających im zatrudnienie"; Arystoteles, Polityka, ks. VI, [w:] idem, Dzieła wszystkie, t. 1, przeł. L. Piotrowicz, Warszawa 2003, s. 154.

15 N. Chomsky, Requiem..., s. 22.

16 Zob. L.F. Powell Jr., Confidential Memorandum. Attack on Free Enterprise System, https:// static1.squarespace.com/static/58894b38ebbd1a2ab75adbe2/t/588cd57dd482e988fc008e 79/1485 6247045 79/Lewis-Powell-Memo.pdf (dostęp: 14.01.2020).

17 Komisja Trójstronna została założona w 1973 roku przez prywatnych obywateli USA, Zachodniej Europy i Japonii w celu dyskusji nad bieżącymi wyzwaniami polityki i rozwijaniu współpracy. Pierwszym przewodniczącym został Zbigniew Brzeziński. Zob. M. Crozier, S.P. Huntington, J. Watanuki, The Crisis of Democracy. Report on Governability of Democracies to the Trilateral Commission, New York 1975. 
3. Przekształcić gospodarkę. Od lat siedemdziesiątych „władcy ludzkości” (przywołując zwrot Adama Smitha) zaczęli dążyć do przekształcenia gospodarki, która do tej pory opierała się na produkcji, na opartą głównie na instytucjach finansowych, jak banki czy fundusze inwestycyjne. W okresie Nowego Ładu, gdy układ z Bretton Woods regulował międzynarodowy system ekonomiczny, nie było krachów finansowych. W latach siedemdziesiątych zniesiono te regulacje i doszło do ogromnego wzrostu przepływu kapitału spekulacyjnego i wielkich zmian w sektorze finansowym, który coraz częściej zaczął sięgać do ryzykownych inwestycji i spekulacji. W tym samym czasie spadło tempo produkcji przemysłowej i zaczęto przenosić produkcję za granicę, gdzie była tańsza siła robocza. W kraju natomiast zaczęto stosować strategię trzymania pracowników w nieustannej niepewności zatrudnienia, co zapewniało większą kontrolę nad nimi. W takich warunkach bali się oni żądać wyższych płac czy godziwych warunków zatrudnienia. To wszystko doprowadziło do koncentracji bogactwa i władzy w rękach nielicznych przy jednoczesnym osłabieniu instytucji publicznych i ubożeniu społeczeństwa. „Główne amerykańskie korporacje osiągają większość zysków za granicą, co daje liczne możliwości przeniesienia ciężaru utrzymywania społeczeństwa na barki pozostałych ludzi"18.

4. Przenieść ciężar. Gospodarka amerykańska rozwijała się bardzo szybko w latach pięćdziesiątych i sześćdziesiątych. Była ona wówczas oparta na produkcji, dlatego biznes dbał o swoich pracowników, którzy jednocześnie byli konsumentami. Henry Ford podniósł pensje swoim pracownikom, by mogli kupować samochody. Dobrobyt kraju upatrywał on we wzroście siły nabywczej drogą zwiększania wynagrodzeń i sprzedaży po niskich cenach. W tych czasach amerykański sen był po części realny, bo sytuacja większości społeczeństwa ulegała poprawie. Chomsky wskazał, że zmieniło się to, gdy neoliberałowie Ronald Reagan i Margaret Thatcher „wprowadzili politykę prowadzącą do wzbogacania się bardzo bogatych”. Wówczas to „plutonomia”, czyli najbogatsi, stali się głównymi konsumentami, dźwignią gospodarki ${ }^{19}$. Wzrost dobrobytu reszty społeczeństwa dla biznesu przestał mieć aż tak duże znaczenie. Również dla polityków, sponsorowanych przez plutonomię, najważniejsze stało się wdrażanie ustaw mających na celu dobro tylko najbogatszych. Klasa średnia tymczasem biedniała i stopniowo stawała się prekariatem, czyli niepewnym pracy i swego losu proletariatem. Politycy tak kształtują system podatkowy, by bogaci płacili coraz niższe podatki,

18 N. Chomsky, Requiem..., s. 45.

19 Ibidem, s. 54. „W plutonomii [...] są konsumenci bogaci, nieliczni, ale mający nieproporcjonalny udział w ogromnych zyskach i konsumpcji. I jest cała reszta, »nie-bogaci« których jest mnóstwo, ale dostają zaskakująco małe kawałki tortu"; ibidem, s. 62. Obecnie badania nad nierównością społeczną prowadzi między innymi organizacja Oxfam, zob. D. Hardoon, S. Ayele, R. Fuentes-Nieva, An Economy For the 1\%. How privilege and power in the economy drive extreme inequality and how this can be stopped, https://www.oxfam.org/en/research/economy-1 (dostęp: 17.01.2020). 
a ciężar wydatków publicznych faktycznie spoczywał na pozostałej, relatywnie biednej, części społeczeństwa. Opodatkowana jest praca, czyli zarobki, oraz konsumpcja, a nie dywidendy i spekulacja. Wzrost bogactwa największych instytucji finansowych wcale nie przyczynia się do zwiększenia inwestycji i miejsc pracy, co próbują wmówić społeczeństwu, tylko do koncentracji bogactwa i władzy. Prywatny biznes nie musi się bowiem starać o głosy większości w żadnych wyborach.

5. Atakować solidarność. Zdaniem Chomsky’ego liberalne rządy i biznes zachęcają ludzi do tego, by kierowali się egoizmem, ponieważ zdają sobie sprawę, że solidarność większości społeczeństwa może doprowadzić do utraty przez nich władzy. Podaje on przykład publicznej edukacji, która opiera się na zasadzie solidarności. Społeczeństwo płaci podatki, by zapewnić wykształcenie i lepszy start kolejnym pokoleniom. W latach pięćdziesiątych społeczeństwo było o wiele biedniejsze niż obecnie, a zapewniało bezpłatną edukację dla weteranów i w większym stopniu fundowało stypendia. Obecnie polityka w każdej sferze podważa solidarności i dlatego państwo wycofało się z zapewnienia ludziom wykształcenia. Podobnie dzieje się ze służbą zdrowia, która w coraz większym stopniu jest sprywatyzowana. Według Chomsky'ego społeczeństwo zyskałoby więcej, gdyby edukacja i służba zdrowia były szeroko dostępne, ale dla instytucji finansowych najważniejsze jest to, by zmniejszać rolę rządu w gospodarce i innych sferach życia społecznego. Wówczas więcej władzy i bogactwa jest w ich rękach.

6. Zarządzanie ciałami nadzorującymi. Chomsky analizując funkcjonowanie urzędów państwowych mających kontrolować różne gałęzie biznesu i instytucje finansowe, zwrócił uwagę, że ten nadzór jest fikcją. Dzieję się tak głównie dzięki efektowi „drzwi obrotowych” (the revolving door), czyli przechodzeniu osób pracujących $w$ administracji rządowej odpowiedzialnych za nadzorowanie instytucji finansowych do tych instytucji i na odwrót. Chomsky jako jeden z przykładów wymienił przypadek Roberta E. Rubina, który przez wiele lat pracował dla Goldman Sachs, był też jego wiceprezesem, a następnie przeszedł do administracji Billa Clintona. Doprowadził do podważenia ustawy Glassa-Steagalla, która dawała gwarancje depozytów przez rząd federalny, oraz do deregulacji innych instrumentów finansowych, tym samym umożliwiając bankom i instytucjom finansowym podejmowanie ryzykownych inwestycji ${ }^{20}$. Następnie Rubin został dyrektorem jednego z największych banków Citigroup i korzystał z tych rozwiązań ustawowych. Za prezydentury Baracka Obamy wrócił do administracji i został doradcą prezydenta, który zgodził się na dofinansowanie Citigroup, gdy ryzykowne transakcje wielu banków nastawione na krótkoterminowy zysk doprowadziły

20 Zob. The Glass-Steagall Act a.k.a. The Banking Act of 1933, An Act to Provide for the Safer and More Effective Use of the Assets of Banks, to Regulate Interbank Control, to Prevent the Undue Diversion of Funds into Speculative Operations, and For Other Purposes; Public Law 73-66, 73d Congress, H.R. 5661, https://www.scribd.com/document/352314041/The-Glass-Steagall-Act-a-k-aThe-Banking-Act-of-1933-pdf (dostęp: 17.01.2020). 
do kryzysu ${ }^{21}$. O ile w czasach New Deal działały mechanizmy regulacyjne i nie było żadnych krachów finansowych, to od lat siedemdziesiątych, gdy rozpoczęła się deregulacja, zaczęły się one pojawiać dość regularnie. „Władza stała się tak skoncentrowana, że banki były nie tylko »zbyt wielkie, aby splajtować«, ale jak wyraził to jeden z ekonomistów, były one też »zbyt wielkie, aby iść do więzienia «"22. Faktycznie instytucje finansowe, będąc przeciwne idei państwa opiekuńczego, same korzystają przy okazji każdego kryzysu z pieniędzy podatników, żądając dofinansowania od państwa. Jak ujął to w jednym z wywiadów Gore Vidal, w Stanach Zjednoczonych mamy socjalizm dla najbogatszych i wolny rynek dla biednych. Chomsky również pisał: „Najprostszą definicją »neoliberalizmu« jest »niech wszystkim rządzi rynek«. Pozbawmy rząd funkcji kształtowania polityki, oprócz wspierania działań rynkowych. Nikt nie ma tego na myśli. Są to środki, które można stosować wobec ubogich i słabych, ale nie wobec siebie"23.

7. Zaaranżować wybory. Koszty kampanii wyborczej rosną w ogromnym tempie, a co za tym idzie — rośnie zależność polityków od sponsorów. „System demokratyczny jest niszczony przez szybki wzrost możliwości kupowania wyborów. [...] W latach siedemdziesiątych sądy zdecydowały, że pieniądze są formą wypowiedzi, wydając orzeczenie w sprawie Buckley kontra Valeo. [...] Oznacza to, że korporacje, które i tak kupują wybory, mogą teraz czynić to bez ograniczeń. To potężny atak na resztkę demokracji" 24 .

8. Trzymać motłoch w ryzach. Zdaniem Chomsky'ego jedynie zorganizowane społeczeństwo tworzy barierę przed wprowadzeniem tyranii. $Z$ tego powodu ta siła demokratyzująca jest atakowana przez „władców ludzkości”, którzy strzegą ustrój przed zbytnią demokratyzacją. Obecnie niecałe 7\% pracowników sektora prywatnego ma związki zawodowe, choć badania pokazują, że w większości są

21 Zob.N.Chomsky, Requiem..., s. 80-81.E. Javers, RobertRubin returns, „Politico”4.08.2010, https:/www.politico.com/story/2010/04/robert-rubin-returns-035515; P. Blumenthal, The Revolving Door, Robert Rubin, and Citigroup, 24.11.2008, https://sunlightfoundation.com/2008/11/24/the-re volving-door-robert-rubin-and-citigroup/ (dostęp: 17.01.2020).

22 N. Chomsky, Requiem..., s. 82.

23 Ibidem, s. 87.

24 Ibidem, s. 97-99. „Buckley kontra Valeo, Sąd Najwyższy Stanów Zjednoczonych, 30 stycznia 1976 roku. Ograniczenie sumy pieniędzy osoby lub grupy, które można wydać na porozumienie polityczne podczas kampanii, siłą rzeczy zmniejsza zakres, ograniczając liczbę dyskutowanych kwestii, dogłębność ich analizy i liczbę słuchaczy, do których ma dotrzeć. Jest tak, ponieważ praktycznie każdy środek komunikacji w dzisiejszym społeczeństwie wymaga nakładów finansowych". Cyt. za: ibidem, s. 104. Więcej na temat wyroku Sądu Najwyższego w sprawie: 424 U.S. 1; Buckley v. Valeo (No. 75-436); Argued: November 10, 1975, Decided: January 30, 1976. Zob. https://www. law.cornell.edu/supremecourt/text/424/1 (dostęp: 17.01.2020). Szerzej na temat kosztów kampanii wyborczych w USA zob. Why American elections cost so much? Because spending on political advertising is protected by the right to freedom of speech, „The Economist” 9.02.2014, https://www. economist.com/the-economist-explains/2014/02/09/why-american-elections-cost-so-much; E. Hornick, Why do U.S. elections cost so much?, https:/edition.cnn.com/2011/10/13/politics/us-electioncosts/index.html (dostęp: 17.01.2020). 
zwolennikami działalności związków ${ }^{25}$. Ważnym elementem utrzymywania społeczeństwa w ryzach jest wyeliminowanie jego świadomości klasowej. „W interesie władzy i przywilejów dobrze jest wybić te idee ludziom z głowy. Nie chcemy, żeby wiedzieli, że są klasą uciskaną. [...] »[K]lasa« stała się brudnym słowem — nie można go wypowiadać" ${ }^{26}$. Władza nie chce, by ludzie mieli świadomość swej sytuacji, bo zaczęliby artykułować interesy swej klasy i dążyć do zniesienia tego skrajnie niesprawiedliwego systemu.

9. Fabrykować zgodę. Chomsky odnosi się do filozofii politycznej Davida Hume'a, który stwierdził, że władza faktycznie jest w rękach rządzonych, bo zawsze są oni większością i mogą połączyć swe siły, by przejąć rządy. Rządzący nie chcą dopuścić do takiej sytuacji. W wolnych krajach, jak Stany Zjednoczone, rządzący nie mogą narzucać swej woli siłą, więc muszą odwoływać się do subtelniejszych środków kontroli społeczeństwa i to jest przyczyna rozwoju przemysłu public relations. Chomsky podkreślał, że propaganda nie powstała w komunizmie czy faszyzmie, lecz w liberalnej demokracji, w czasach I wojny światowej, gdy Komitet do spraw Informacji Publicznej w Stanach Zjednoczonych i Ministerstwo Informacji w Wielkiej Brytanii przekonały społeczeństwa do wojny z Niemcami ${ }^{27}$. Ten sukces zainteresował elity chcące manipulować masami oraz biznes poszukujący coraz to nowych konsumentów. Dało to początek rozwojowi przemysłu public relations. Czołową postacią, która przyczyniła się do jego rozwoju, był Edward Bernays, który w 1928 roku opublikował książkę Propaganda. Była ona $\mathrm{w}$ istocie podręcznikiem prezentującym teoretyczne zasady działania powstającego public relations. Opierały się one na przeświadczeniu, że rządzić powinna ,inteligentna mniejszość” („,czyli oczywiście my”), która musi fabrykować zgodę na swoje rządy pozostałej „tępej” części społeczeństwa. To właśnie jest podstawowy cel public relations.

Świadome i inteligentne manipulowanie nawykami i opiniami mas jest ważnym elementem społeczeństwa demokratycznego. Ci, którzy manipulują tym niewidocznym mechanizmem, stanowią niewidzialny rząd, który stanowi prawdziwą panującą władzę w naszym kraju. Jesteśmy rządzeni, nasze umysły są kształtowane, nasze upodobania urabiane, nasze poglądy kreowane, głównie przez ludzi, o których nigdy nie słyszeliśmy. [...] Naszą demokracją musi kierować inteligentna mniejszość, która wie, jak organizować masy i nimi kierować ${ }^{28}$.

25 N. Chomsky, Requiem..., s. 111. „Union membership peaked in 1954 at nearly $35 \%$ of all U.S. workers (excluding the self-employed), but in 2018 the unionization rate was just $10.5 \%$ \%; D. Desilver, 10 facts about American workers, https://www.pewresearch.org/fact-tank/2019/08/29/ facts-about-american-workers/; tam też więcej na temat związków w USA. Zob. też U.S. Bureau of Labor Statistics, Union Members Summary, https://www.bls.gov/news.release/union2.nr0.htm (dostęp: 22.01.2020).

${ }^{26}$ N. Chomsky, Requiem..., s. 113.

27 N. Chomsky, Propaganda and the Public Mind. Conversations with Noam Chomsky. Interviws with David Barsamian, Cambridge 2001, s. 151.

28 E.L. Bernays, Propaganda, New York 1928; cyt. za: N. Chomsky, Requiem..., s. 131-132 (polskie wydanie: E.L. Bernays, Propaganda, przeł. R. Wierzchoń, Kobierzyce 2020). Więcej na temat poglądów Bernaysa zob. M. Lakomy, Doktryna Bernaysa: demokracja - między propaganda 
Zwolennikiem tej doktryny był też Walter Lippmann, który w swoich licznych esejach o demokracji dowodził, że tylko osoby odpowiedzialne powinny podejmować decyzje polityczne, nie zważając na dążenia „oszołomionego tłumu"29. Kontrolować tłum można poprzez fabrykowanie potrzeb, czyli ukierunkowanie ich na konsumpcję w istocie niepotrzebnych rzeczy, która staje się celem życia $^{30}$. Ludzie muszą więc podejmować irracjonalne wybory. „Kiedy te same instytucje - system PR - kierują wyborami, czynią to w taki sam sposób. Pragną stworzyć niezorientowanych wyborców, którzy dokonają nieracjonalnego wyboru, często wbrew własnym interesom"31. PR nie odwołuje się do racjonalnych argumentów, ale do wyabstrahowanych marzeń o blichtrze, powodzeniu i wyższości nad innymi. Celem jest sprzedanie towaru, w przypadku wyborów zaś „sprzedanie” kandydatów. Z tego względu oczy społeczeństwa kieruje się na pozory i sprawy marginalne, którymi łatwo manipulować. „Próbują uczynić z ludzi irracjonalne stworzenia i wkładają w to wiele wysiłku. I myślę, że mają rację. Nie marnują pieniędzy. Gdyby tego nie robili, ludzie podejmowaliby racjonalne decyzje, i myślę, że racjonalne decyzje zlikwidowałyby nielegalną władzę i hierarchiczne instytucje" 32 .

10. Zmarginalizować ludność. W demokracji wybrani politycy powinni realizować wolę wyborców. Chomsky przytacza badania dwóch politologów, Martina Gilensa i Benjamina Page'a, w których wzięli oni pod uwagę ponad 1700 decyzji politycznych i zestawiali je z odmiennymi oczekiwaniami społeczeństwa i biznesu. Wyniki były jednoznaczne: decyzje polityczne są skorelowane tylko $\mathrm{z}$ oczekiwaniami wielkich korporacji. Nie ma w tym nic dziwnego, ponieważ to $1 \%$ najbogatszych (Chomsky szacuje, że w istocie nawet mniej, około promila) faktycznie rządzi. Udowodnili też, że $70 \%$ społeczeństwa nie ma żadnego wpływu na politykę i w zasadzie mogliby żyć w innym kraju ${ }^{33}$. Chomsky uważa, że właśnie to jest powodem niechęci, a nawet wrogości społeczeństwa wobec instytucji politycznych i finansowych. Coraz większy gniew społeczeństwa jest jednak zazwyczaj nieukierunkowany i ma charakter autodestrukcyjny. „Chodzi o to, aby nawzajem się nienawidzili i lękali, aby dbali tylko o siebie i nie robili nic dla innych" ${ }^{34}$. Ten gniew i strach wykorzystują politycy, jak Donald Trump. Popiera go głównie klasa robotnicza oraz biedniejąca od lat siedemdziesiątych

a public relations, Kraków 2019. Bernays był tym, który zorganizował wielką kampanię reklamową zachęcającą kobiety do palenia w latach trzydziestych, przekonując, że jest to modne.

29 Zob. N. Chomsky, Requiem..., s. 124.

30 Zob. ibidem, s. 125. Thorstein Veblen nazwał to „fabrykowaniem konsumentów”; idem, Teoria klasy próżniaczej, przeł. J. Frentzel-Zagórska, Warszawa 1998 (The Theory of the Leisure Class, 1899).

31 N. Chomsky, Requiem..., s. 128.

32 Ibidem, s. 129.

33 Zob. M. Gilens, B.I. Page, Testing theories of American politics: Elites, interest groups, and average citizens, „Perspectives on Politics” 12, 2014, nr 3, s. 564-581.

34 N. Chomsky, Requiem..., s. 138. 
klasa średnia, która nie czuje się reprezentowana nawet przez wybranych przez siebie polityków. Mają oni poczucie, że tracą swój kraj, bo „inni” go zabierają. Neoliberalni politycy manipulują kategorią ,inni”, zrzucając winę za sytuację nie na najbogatszą elitę, która doprowadziła do tej sytuacji i na niej nieustannie zarabia, ale na najsłabsze, niemające sił się bronić grupy, jak emigranci i wszelkiego rodzaju mniejszości. Głoszą jednocześnie, że najlepszym rozwiązaniem jest jeszcze więcej neoliberalizmu, deregulacji, mniej państwa i więcej biznesu. Celem jest bowiem całkowita marginalizacja społeczeństwa i skoncentrowanie bogactwa i władzy w rękach promila najbogatszych.

\section{Chomsky o zagrożeniach wynikających z obecnych struktur władzy}

Zdaniem Chomsky'ego istniejące struktury władzy niosą za sobą tragiczne w skutkach konsekwencje praktycznie na każdej płaszczyźnie życia społeczno-politycznego. Przede wszystkim promowanie wartości, na których opiera się neoliberalizm, czyli egoizmu, zachłanności i realizowania własnych korzyści kosztem innych, doprowadzi do całkowitego zaniku więzi społecznych, takich jak solidarność, empatia, wspieranie się, które zdaniem Chomsky'ego czynią społeczeństwo silnym, zdolnym do rozwoju i pokojowej egzystencji. Dezintegracja społeczna i chaos będą konsekwencją obecnych struktur władzy. W obliczu tego zagrożenia Chomsky stawia nawet pytanie, czy nasz gatunek przetrwa, ,przynajmniej w jakiejś przyzwoitej postaci? Oto prawdziwy problem"35. Zagrożeniem jest również nadciągająca katastrofa ekologiczna, tymczasem Partia Republikańska promuje zwiększenie wykorzystania paliw kopalnych, a prezydent Donald Trump ogłosił w 2017 roku wycofanie Stanów Zjednoczonych z uzupełniającego ramową konwencję Narodów Zjednoczonych w sprawie zmian klimatu porozumienia paryskiego, które wymaga ograniczenia emisji gazów cieplarnianych. Jest to znów działanie w interesie wielkich korporacji, a nie społeczeństwa, które musi się zmagać z konsekwencjami ekonomicznymi i zdrowotnymi zmian klimatycznych, jak powodzie, susze, zanieczyszczone powietrze i woda. Znów wzbogacą się najbogatsi, a zapłaci za to coraz biedniejsza większość. Zdaniem Chomsky'ego nadal musimy też stawiać czoła groźbie wojny jądrowej, która może być rezultatem nastawionej na zyski polityki wielkich korporacji.

Przedstawiony model faktycznych struktur władzy ma zgubny wpływ na całą ludzkość. Chomsky uważa, że mamy szanse zmienić ten stan rzeczy, bo, jak pisał, poprzednie pokolenia wywalczyły dla nas sporą sferę wolności, w tym wolność słowa i zrzeszania się. Jest to tak ważne, ponieważ uczymy się poprzez relacje, a więc niezbędne są wszelkiego rodzaju debaty w każdej sferze, w tym

35 Ibidem, s. 141. 
akademickiej, oraz organizowanie się w różnego typu stowarzyszenia i związki zawodowe, w ramach których rodzi się współpraca i solidarność. To ruchy społeczne są w stanie faktycznie demokratyzować poszczególne sfery życia społeczno-politycznego. Zdaniem Chomsky'ego nie ma bowiem jednego remedium na wszystko. Różne ruchy społeczne muszą rozwiązywać konkretne problemy. Chomsky przytoczył słowa swojego przyjaciela Howarda Zinna, który był przekonany, że „to, co się liczy, to niezliczone drobne czyny nieznanych ludzi, którzy tworzą podstawę do ważnych wydarzeń, które wejdą do historii" ${ }^{36}$. Jest to jedyna droga, by rozbić tak skoncentrowaną władzę najbogatszych i zakonserwowaną przez nich strukturę społeczną (business-run society). Odwołując się do poglądów Johna Deweya, Chomsky zaznaczył, że przede wszystkim produkcja, handel i media powinny znaleźć się pod bezpośrednią demokratyczną kontrolą. Noam Chomsky wskazał tylko na drogę, bo jak pisał: „Nie sądzę, abyśmy byli na tyle mądrzy, aby obmyśleć szczegółowo, jakie powinno być sprawiedliwe i wolne społeczeństwo. Myślę, że możemy dostarczyć pewnych wskazówek i, co ważne,

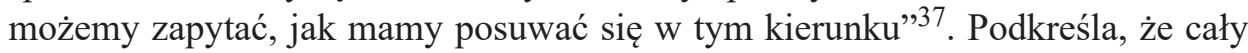
czas powinniśmy też zadawać pytanie, dlaczego istnieją struktury władzy, dominacja, hierarchia. Jego zdaniem struktury, w których ktoś wydaje polecenia, a ktoś musi je wykonywać, nie usprawiedliwiają się, bo negują wolność. Zadaniem nie jest więc wytworzenie tylko demokratycznej kontroli władzy, ale też stawianie pytania, dlaczego ona w ogóle istnieje. Ten sposób myślenia wynika z klasycznego liberalnego myślenia. „Stanowi to także rdzeń anarchizmu, ale oznacza również demokrację. Nie uważam, aby były ze sobą w sprzeczności. To po prostu różne sposoby patrzenia na ten sam problem — podejmowanie decyzji w rękach ludzi, którzy się zajmują decyzjami i ich skutkami”38.

Interesujące jest to, że swoją książkę Chomsky zatytułował Requiem dla amerykańskiego snu i we wstępie stwierdził jednoznacznie, że ten sen umarł. Jednak w ostatnim rozdziale wyraża on głębokie przekonanie, że ruchy społeczne będą w stanie doprowadzić do demokratyzacji życia społecznego. Chomsky nadal żyje więc nadzieją, że ten sen o demokracji kiedyś się spełni.

\section{Poglądy Noama Chomsky'ego jako jeden z nurtów Nowej Lewicy (New Left)}

Poglądy Noama Chomsky’ego wpisują się w nurt myśli politycznej i liczne ruchy społeczne określane wspólnie mianem Nowej Lewicy. On sam powołuje się i docenia działalność ruchów społecznych lat sześćdziesiątych i siedemdziesiątych,

\footnotetext{
36 Ibidem, s. 148 .

37 Ibidem, s. 144.

38 Ibidem, s. 145.
} 
które organizowały się w ośrodkach akademickich, by później oddziaływać szerzej na społeczeństwo i doprowadzić między innymi do zniesienia segregacji rasowej ${ }^{39}$. Podnosiły one wagę praw mniejszości oraz krytykowały opresyjność systemów państwowych i prowadzenie wojen mających na celu utrzymanie imperialnego statusu Stanów Zjednoczonych. Podstawowym ich celem było wolne i demokratyczne społeczeństwo. Symbolem amerykańskiej Nowej Lewicy stała się organizacja Students for a Democratic Society, która za ideał uważała demokrację uczestniczącą (participatory democracy) ${ }^{40}$. Także przywódcy i działacze The Civil Rights Movement, jak Martin Luther King, pragnęli demokracji, która zapewnia wszystkim obywatelom wolność i równość. King w kazaniu, które wygłosił w 1957 roku w Montgomery, mówił:

Moim zdaniem demokracja jest najlepszą formą rządów, jaką wymyślił człowiek. Jej słabość polega jednak na tym, że nigdy jej nie osiągnęliśmy. Czyż nie jest prawdą, że często odbieraliśmy podstawowe środki do życia masom, by zapewnić je klasom? Czyż nie jest prawdą, że często w naszej demokracji depczemy jednostki i rasy żelazną stopą ucisku? Czyż nie jest prawdą, że zachodnie mocarstwa napędzały kolonializm i imperializm ${ }^{41}$

Działaczy The Civil Rights Movement opisywał King jako tych, którzy „powstali w obronie amerykańskiego mitu i którzy chcieli przypomnieć Ameryce o wartościach demokracji, której fundamenty zostały mocno osadzone przez ojców założycieli w Deklaracji Niepodległości i Konstytucji”" ${ }^{2}$. Nowa Lewica, w tym Noam Chomsky, wskazywała na hipokryzję systemu: zapisy Konstytucji mówią o demokracji i prawach obywatelskich, tymczasem demokracja, czyli możliwość faktycznego i równego współudziału większości społeczeństwa w kreowaniu polityki, nie istnieje ${ }^{43}$. Chomsky, pisząc o rzeczywistych strukturach władzy, pragnie uświadomić czytelnikom, że amerykański sen o demokracji

39 Dwa najważniejsze akty prawne, które znosiły segregację i zostały uchwalone pod wpływem aktywności jednego z ruchów Nowej Lewicy, The Civil Rights Movement, to uchwalony w 1964 roku The Civil Rights Act (pełny tytut: An act to enforce the constitutional right to vote, to confer jurisdiction upon the district courts of the United States of America to provide injunctive relief against discrimination in public accommodations, to authorize the Attorney General to institute suits to protect constitutional rights in public facilities and public education, to extend the Commission on Equal Employment Opportunity, and for other purposes, http://library.clerk.house.gov/ reference-files/PPL_CivilRightsAct_1964.pdf, dostęp: 27.01.2020) oraz uchwalony w 1965 roku The Voting Rights Act (pełny tytul: An act to enforce the fifteenth amendment of the Constitution of the United States, and for other purposes, http://library.clerk.house.gov/reference-files/PPL_VotingRightsAct_1965.pdf, dostęp: 27.01.2020).

40 Zob. R. Tokarczyk, Nowa Lewica. Rodowód - ruchy - ideologia - recepcja, Kraków 2010, s. 60 .

${ }^{41}$ M.L. King, Mitujcie nieprzyjaciót waszych, [w:] idem, „I have a dream”. Stowa zburzyty mury, przeł. G. Kość, G. Zawora, red. B. Szklarski, P. Średziński, Warszawa 2014, s. 79.

42 M.L. King, Widze ziemię obiecana, 3 kwietnia 1968, [w:] idem, ,, I have a dream "..., s. 187.

43 „Także inne nurty współczesnej radykalnej amerykańskiej myśli społecznej wskazują niekiedy na hipokryzję jako na jedną z głównych cech systemu amerykańskiego. [...] Wszystkie reformistyczne ugrupowania Nowej Lewicy utrzymywały, że oficjalna ideologia Stanów Zjednoczo- 
się nie ziścił, bo większość społeczeństwa nie ma żadnego wpływu na faktyczne decyzje polityków ${ }^{44}$. Przedstawiciele Nowej Lewicy wskazujący na hipokryzję systemu faktycznie istniejące struktury władzy określili mianem „państwa korporacyjnego".

W amerykańskim państwie korporacyjnym brak miejsca dla współuczestniczenia społeczeństwa we władzy choćby na zasadach demokracji przedstawicielskiej. Wyparta została ona w procesach oligarchizacji i technokratyzacji władzy politycznej. [...] Oligarchizacja, opisana m.in. przez Ch.W. Millsa, to skupienie pełni władzy politycznej i ekonomicznej przez mała grupę ludzi, dysponujących wielkim kapitałem i związanych z najwyższymi przedstawicielami administracji państwowej i hierarchii wojskowej. Technokratyzacja natomiast, znana [...] głównie w wersji J. Burnhama, wyraża się w przekazywaniu przez oligarchię aktu podejmowania najważniejszych decyzji specjalistom do rządzenia, menedżerom wielkiej polityki i wielkiego biznesu, zależnym ekonomicznie od oligarchii ${ }^{45}$.

Podkreślano, że ten typ państwa ma charakter totalitarny, bo opiera się na przemocy i prowadzi do całkowitego podporządkowania sobie rządzonych. Wprawdzie nie jest to bezpośrednia brutalna przemoc, która — jak pokazała historia - nie zapewnia trwania władzy, lecz za pomocą represji psychicznych w sposób pośredni osiąga się te same rezultaty. Środki masowego przekazu, reklamy, inne nowoczesne kanały komunikacji oraz system szkolnictwa narzucają takie wzorce życiowe i wpajają agresywne potrzeby, które czynią z ludzi jednowymiarowe istoty skoncentrowane tylko na konsumpcji ${ }^{46}$. Ludzie w ten sposób stają się częścią kapitalistycznego systemu. „Jednowymiarowość kształtowana i podtrzymywana przez amerykański system polityczny ogranicza wolność jednostek; charakteryzuje ją wysoki stopień represywności prowadzącej do totalitaryzmu" 47 . Nie wszyscy przedstawiciele Nowej Lewicy tak radykalnie oceniali system polityczny Stanów Zjednoczonych. W Requiem dla amerykańskiego snu Chomsky również nie pisał o totalitaryzmie. Nawiązuje raczej do stworzonej przez lewicowych myślicieli Michaela Hardta i Antonia Negriego koncepcji imperium, tożsamego z władzą przenikającą wszystkie elementy życia społecznego, politycznego i gospodarczego ${ }^{48}$. Dąży ona do ograniczenia podmiotowości zarówno swoich obywateli, jak i mieszkańców państw zależnych.

nych mogłaby zyskać na wartości dopiero wtedym gdyby została poparta zgodną z nią praktyką". R. Tokarczyk, op. cit., s. 86.

44 Warto w tym miejscu przytoczyć refleksję Jürgena Habermasa, teoretyka Nowej Lewicy, który w Filozoficznym dyskursie nowoczesności skonstruował narrację rozwoju społeczeństwa Zachodu i wysnuł wniosek o rozszerzających się nożycach pomiędzy tym, co wiemy, a tym, jak społeczeństwa faktycznie egzystują. Zob. J. Węgrzycki, Wpływ, autorytet, dominacja. Teorie władzy i ich struktura, Warszawa 2011, s. 215-243.

45 R. Tokarczyk, op. cit., s. 87.

46 Pojęcie człowieka jednowymiarowego do dyskursu naukowego i politycznego wprowadził Herbert Marcuse. Zob. idem, One Dimensional Man: Studies in the Ideology of Advanced Industrial Society, Boston 1964; L. Kołakowski, Główne nurty marksizmu, t. 3, Warszawa 2009, s. 406-409.

47 R. Tokarczyk, op. cit., s. 88.

48 Zob. M. Hardt, A. Negri, Imperium, przeł. S. Ślusarski, A. Kołbaniuk, Warszawa 2005. 


\section{Zakończenie}

Chomsky podjął się zadania systematycznego opracowania faktycznych zasad funkcjonowania struktur władzy Stanów Zjednoczonych. Stwierdził, że mamy do czynienia $\mathrm{z}$ koncentracją bogactwa $\mathrm{i}$ władzy $\mathrm{w}$ rękach niewielkiej grupy najbogatszych. Pokazał, w jaki sposób przejmują oni efektywnie kontrolę nad społeczeństwem i politykami. W istocie Stany Zjednoczone nie są demokracją przedstawicielską. Rozważania te są interesujące zarówno pod kątem opisywania współczesnych ustrojów państwowych, jak i debat nad rolą prawa. Podkreślając hipokryzję systemu, Chomsky wskazał na dysonans między zapisami Konstytucji i systemem prawa ustanawiającym demokrację przedstawicielską, gwarantującym prawa obywatelskie, a rzeczywistością polityczną. Oznacza to, że prawo nie gwarantuje realizacji wprost zapisanych zasad, ponieważ jego interpretacja i stosowanie są zależne od interesów podmiotów faktycznie dzierżących władzę. Należy zadać pytanie, czy można mówić o demokracji w kraju, w którym panowała segregacja rasowa i tak duża grupa obywateli jak Afroamerykanie nie mogła korzystać z praw obywatelskich. Inny przykład fikcyjnego prawa to chociażby obowiązek kontroli instytucji finansowych. Jest ono formalnie przestrzegane, lecz funkcjonująca zasada „drzwi obrotowych” powoduje, że w rzeczywistości instytucje te, za pośrednictwem swoich byłych i przyszłych, dobrze opłacanych pracowników, nie są kontrolowane. Szczególne znaczenie dla unicestwienia demokracji mają też zasady finansowania coraz droższych kampanii wyborczych i cały system lobbingu polityków oraz manipulowania społeczeństwem dzięki mediom masowym i społecznościowym. Prawo w tym świetle zaczyna się wydawać tylko piękną fasadą, a nie realną siłą organizującą życie społeczne i polityczne. Władza nie realizuje zapisów Konstytucji, lecz wykorzystuje je, by zakamuflować przed opinią publiczną swe faktyczne działania ${ }^{49}$.

Celem Chomsky'ego jest demaskacja faktycznych struktur władzy i dotarcie do jak największej liczby czytelników, ponieważ uważa, że świadomi tych mechanizmów obywatele dzięki wolności zrzeszania się i wolności słowa są w stanie zmienić ten stan rzeczy ${ }^{50}$. Jak ważna jest świadomość tego, co się dzieje wokół nas, wydaje się oczywiste. Warto w tym miejscu przytoczyć fragment

49 W tym miejscu warto zwrócić uwagę, że w takim razie sama znajomość przepisów prawa, w tym prawa konstytucyjnego, nie daje pełni wiedzy o tym, gdzie usytuowana jest władza i jak ona funkcjonuje. Dlatego edukacja prawnicza powinna być „dopełniona” przez taki przedmiot jak doktryny polityczno-prawne, które z szerszej perspektywy odnoszą się do problematyki państwa, prawa i samej władzy. Zob. M. Baranowska, Doktryny polityczno-prawne jako jeden z filarów edukacji prawniczej, „Studia Iurdica Toruniensia” 2013, z. 2, s. 11-28.

50 Chomsky zmaga się „z epistemologicznymi odkształceniami naszego dyskursu politycznego”. Chce on „doprowadzić do szczerej i bolesnej konfrontacji naszych społeczeństw z otaczającą rzeczywistością, której nie jesteśmy w stanie w pełni poznawać, gdyż narzucane nam schematy myślenia zakłócają poprawne jej diagnozowanie. Odczarowanie pozwoli nam nie tylko na pełne zrozumienie świata, lecz również na odkrycie, że możemy działać wspólnie i realizować solidarnie 
rozmowy Ryszarda Kapuścińskiego z biednymi chłopami w Meksyku, którzy skarżyli się na wszystko, ale byli pokorni, nie buntowali się. Kapuściński spytał ich: „»Dlaczego nie walczycie?« Zapadła cisza, a po chwili padła odpowiedź: »Bo nie mamy świadomości, señor«. Dla nich świadomość to narzędzie takie jak motyka, jak siekiera, to coś materialnego. To nawet jakby luksus. Człowieka biednego nie stać na to, by mieć świadomość" 51 . Wydaje się, że Chomsky chce dać broń do ręki ludzi, by ci, tak jak poprzednie pokolenia, nie ustawali w walce o wolność i demokrację.

\section{Bibliografia}

An act to enforce the constitutional right to vote, to confer jurisdiction upon the district courts of the United States of America to provide injunctive relief against discrimination in public accommodations, to authorize the Attorney General to institute suits to protect constitutional rights in public facilities and public education, to extend the Commission on Equal Employment Opportunity, and for other purposes, http://library.clerk.house.gov/reference-files/ PPL_CivilRightsAct_1964.pdf.

An act to enforce the fifteenth amendment of the Constitution of the United States, and for other purposes, http://library.clerk.house.gov/reference-files/PPL_VotingRightsAct_1965.pdf.

Adams J.T., The Epic of America, Boston 1931, https://archive.org/stream/in.ernet.dli.2015.2623 85/2015.262385.The-Epic_djvu.txt.

Arystoteles, Polityka, [w:] idem, Dzieła wszystkie, t. 1, przeł. L. Piotrowicz, Warszawa 2003.

Baranowska M., Doktryny polityczno-prawne jako jeden z filarów edukacji prawniczej, „Studia Iurdica Toruniensia" 2013, z. 2, s. 11-28.

Bernays E.L., Propaganda, przeł. R. Wierzchoń, Kobierzyce 2020.

Blumenthal P., The Revolving Door, Robert Rubin, and Citigroup, 24.11.2008, https://sunlightfoun dation.com/2008/11/24/the-revolving-door-robert-rubin-and-citigroup/.

Buckley v. Valeo (No. 75-436); Argued: November 10, 1975; Decided: January 30, 1976; https:// www.law.cornell.edu/supremecourt/text/424/1.

Chomsky N., Hegemonia albo przetrwanie. Amerykańskie dążenie do globalnej dominacji, przeł. W. Turopolski, Warszawa 2005.

Chomsky N., Propaganda and the Public Mind. Conversations with Noam Chomsky. Interviews with David Barsamian, Cambridge 2001.

Chomsky N., Requiem dla amerykańskiego snu. 10 zasad koncentracji bogactwa $i$ władzy, przeł. S. Baranowski, Kraków 2018.

Crozier M., Huntington S.P., Watanuki J., The Crisis of Democracy. Report on Governability of Democracies to the Trilateral Commission, New York 1975.

Cullen J., The American Dream: A Short History of an Idea That Shaped a Nation, Oxford 2003.

Desilver D., 10 facts about American workers, https://www.pewresearch.org/fact-tank/2019/08/29/ facts-about-american-workers/.

Garland C., Noam Chomsky, [hasło w:] The International Encyclopedia of Revolution and Protest: 1500 to the Present, red. I. Ness, Oxford-New York 2009, s. 738-739.

rzeczy, co nieustannie uniemożliwiają obecne elity władzy". B. Pieliński, Odczarowanie Noama Chomsky'ego, „Problemy Polityki Społecznej” 2007, nr 10, s. 53.

51 R. Kapuściński, Lapidarium I, [w:] idem, Lapidaria I-III, Warszawa 2008, s. 21.

Studia nad Autorytaryzmem i Totalitaryzmem 42, nr 4, 2020

(C) for this edition by CNS 
Gilens M., Page B.I., Testing theories of American politics: Elites, interest groups, and average citizens, „Perspectives on Politics” 12, 2014, nr 3, s. 564-581.

The Glass-Steagall Act a.k.a. The Banking Act of 1933, An Act to Provide for the Safer and More Effective Use of the Assets of Banks, to Regulate Interbank Control, to Prevent the Undue Diversion of Funds into Speculative Operations, and For Other Purposes; Public Law 73-66, 73d Congress, H.R. 5661; https://www.scribd.com/document/352314041/The-Glass-SteagallAct-a-k-a-The-Banking-Act-of-1933-pdf.

Hardoon D., Ayele S., Fuentes-Nieva R., An Economy For the 1\%. How privilege and power in the economy drive extreme inequality and how this can be stopped, https://www.oxfam.org/en/ research/economy-1.

Hardt M., Negri A., Imperium, przeł. S. Ślusarski, A. Kołbaniuk, Warszawa 2005.

Hornick E., Why do U.S. elections cost so much?, https:/edition.cnn.com/2011/10/13/politics/us -election-costs/index.html.

Javers E., Robert Rubin returns, „Politico” 4.08.2010, https://www.politico.com/story/2010/04/rob ert-rubin-returns-035515.

Kapuściński R., Lapidaria I-III, Warszawa 2008.

King M.L., „I have a dream”. Stowa zburzyly mury, przeł. G. Kość, G. Zawora, red. B. Szklarski, P. Średziński, Warszawa 2014.

Kołakowski L., Główne nurty marksizmu, t. 3, Warszawa 2009.

Lakomy M., Doktryna Bernaysa: demokracja - między propaganda a public relations, Kraków 2019.

Marcuse H., One Dimensional Man: Studies in the Ideology of Advanced Industrial Society, Boston 1964.

Pieliński B., Odczarowanie Noama Chomsky'ego, „Problemy Polityki Społecznej” 2007, nr 10, s. $53-62$.

Powell Jr. L.F., Confidential Memorandum. Attack on Free Enterprise System, https://static1.squa respace.com/static/58894b38ebbd1a2ab75adbe2/t/588cd57dd482e988fc008e79/148562 4704579/Lewis-Powell-Memo.pdf.

Shakespeare W., Tragiczna historia Hamleta, księcia Danii, przeł. M. Słomczyński, Kraków 2004. Tokarczyk R., Nowa Lewica. Rodowód - ruchy - ideologia - recepcja, Kraków 2010.

U.S. Bureau of Labor Statistics, Union Members Summary, https://www.bls.gov/news.release/un ion2.nr0.htm.

Veblen T., Teoria klasy próżniaczej, przeł. J. Frentzel-Zagórska, Warszawa 1998.

Węgrzycki J., Wplyw, autorytet, dominacja. Teorie władzy i ich struktura, Warszawa 2011.

Why American elections cost so much? Because spending on political advertising is protected by the right to freedom of speech, „The Economist” 9.02.2014, https://www.economist.com/ the-economist-explains/2014/02/09/why-american-elections-cost-so-much. 